\title{
AKTIVITAS ANTIBAKTERI EKSTRAK ALGA LAUT Caulerpa racemosa DARI PERAIRAN PULAU NAIN
}

\author{
Marina Flora Oktavine Singkoh ${ }^{1}$
}

\begin{abstract}
Algae or seaweed is the dominant part of marine plants. Morphologically, it is categorized as non-vascular plants (Thallophyta) because it has no specific structural configuration such as roots, stems and leaves. This marine algae is found abundantly in the waters of Pulau Nain. Algae from these waters was tested in the laboratory to obtain pharmaceutical preparations to be used as antibacterial active ingredients. This study was carried out to determine the antibacterial activity of the Caulerpa racemosa algae. Antibacterial activity test showed that the test solution of $C$. racemosa algae has antibacterial activity on all five test bacteria. The size of inhibition zones formed was relatively smaller, when compared to the size of inhibition zone formed by the comparative antibiotic compounds.
\end{abstract}

Keywords: Caulerpa racemosa, seaweed, antibiotic.

\begin{abstract}
ABSTRAK
Alga atau ganggang laut (seaweed) adalah bagian terbesar dari tumbuhan laut, dimana secara morfologi dapat dikelompokkan kedalam golongan tumbuhan tidak berpembuluh (Thallophyta) karena tidak memiliki perbedaan susunan kerangka seperti akar, batang dan daun. Berdasarkan pengamatan di lapangan, alga laut banyak ditemukan di daerah perairan Pulau Nain. Dari perairan ini selanjutnya dilakukan pengujian secara laboratories untuk memperoleh sediaan farmasi yang digunakan sebagai bahan aktif antibakteri. Penelitian ini dilakukan dengan tujuan untuk menentukan aktivitas antibakteri dari alga Caulerpa racemosa. Hasil pengujian aktivitas antibakteri menunjukkan bahwa larutan uji dari alga $C$. racemosa memiliki aktivitas antibakteri pada ke 5 bakteri uji yang diujikan. Ukuran zona hambat yang terbentuk relatif lebih kecil, jika dibandingkan dengan ukuran zona hambat yang dibentuk oleh senyawa antibiotika pembanding.
\end{abstract}

Kata kunci: Caulerpa racemosa, ganggang laut, antibiotik.

\footnotetext{
${ }^{1}$ Staf pengajar Fakultas Matematika dan IImu Pengetahuan Alam, Universitas Sam Ratulangi.
}

\section{PENDAHULUAN}

Pemanfaatan alga laut dalam bidang farmasi selama ini masih terbatas, sedangkan potensi alga laut di Indonesia lebih khusus di Sulawesi Utara sangat besar. Potensi alga laut (makroalga) Indonesia sangat besar untuk dikembangkan sebagai bahan baku obat. Dalam pengobatan tradisional, alga laut telah lama digunakan untuk keperluan pengobatan berbagai jenis penyakit, seperti penurun panas, eksim, batu empedu, gondok, gangguan ginjal dan gangguan perut. Dari hasil studi Tjaniadi, et al. (2003) ditemukan beberapa bakteri patogen yang telah resisten terhadap antibiotika ampisilin, kotrimoxasol, dan tetrasiklin, sehingga sekarang ini banyak penelitian yang dilakukan untuk mengeksplor manfaat alga sebagai bahan dasar untuk obatobatan. Beberapa hasil penelitian antibakteri telah dilakukan dengan menggunakan organisme laut, seperti penelitian Sulistijo, et al. (1993) dalam Atmadja (1996), beberapa alga yang berasal dari perairan Indonesia ditemukan memiliki senyawa aktif 
yang sifatnya sebagai antimikroba terhadap bakteri pathogen, salah satunya adalah dari genus Caulerpa. Penelitian oleh Rianida (2007), menunjukkan bahwa ekstrak Caulerparacemosa var. uvifera (Turner) Weber Va Bosse mengandung senyawa antibakteri yang dapat menghambat pertumbuhan beberapa bakteri seperti E. Coli, Staphylococcus aureus dan Bacillus subtilis. Berdasarkan hal tersebut, eksplorasi sumberdaya alam yang dapat dijadikan sebagai senyawa antibakteri terus dilakukan untuk tetap menjaga ketersediaan senyawa antibakteri. Senyawa antibakteri ini harus efektif dalam pengendalian pertumbuhan bakteri dan masalah resistensi terhadap bahan yang digunakan, khususnya bakteri yang merugikan manusia.

Berdasarkan pengamatan di lapangan, alga laut banyak ditemukan di daerah perairan Pulau Nain. Dari perairan ini selanjutnya dilakukan pengujian secara laboratoris untuk memperoleh sediaan farmasi yang digunakan sebagai bahan aktif antibakteri.

Dalam rangka eksplorasi sumberdaya alam yang dapat dijadikan sebagai bahan sediaan farmasitika maka dilakukan penelitian mengenai alga. Penelitian mengenai alga yang telah dilakukan hingga sekarang sebagian besar hanya membahas aspek biologisnya, sedangkan penelitian tentang uji aktivitas, lebih khusus sebagai bahan antibakteri belum banyak dilakukan. Berdasarkan hal tersebut, maka dilakukan penelitian ini.

Penelitian ini bertujuan untuk menentukkan aktivitas antibakteri dari alga laut Caulerpa racemosa. Sampel alga ini diambil di perairan pesisir Pulau Nain, Kabupaten Minahasa Utara, Sulawesi Utara.

\section{METODE PENELITIAN}

\section{Penanganan Sampel}

Sampel alga yang digunakan setelah diambil dari air dimasukan dalam kantong plastik kemudian diletakan dalam kotak pendingin. Setelah itu dilanjutkan dengan proses maserasi dan ekstrasi.

Sampel segar alga masing-masing sebanyak $1 \mathrm{~kg}$ dihaluskan dengan blender kemudian dimaserasi dengan etanol teknis.
Kemudian filtrat disaring dengan menggunakan kertas whatman. Kemudian pelarut diuapkan dengan menggunakan alat rotary evaporator Buchi Rotavapor R-205 dan sisa pelarut yang mungkin tersisa diuapkan dengan freeze dry Labconco Freeze dry System/Freezone ${ }^{\circledR}$ 4.5. Ekstrak yang diperoleh ditimbang dengan menggunakan neraca analitik, sehingga diperoleh ekstrak kasar etanol.

\section{Pembuatan Agar Miring}

Bahan yang digunakan dalam pembuatan agar miring ini adalah agar $2 \mathrm{~g}$, nutrien agar $3,2 \mathrm{~g}$, dilarutkan dalam $120 \mathrm{ml}$ akuades di atas penangas setelah itu media dituangkan ke dalam tabung reaksi. Selanjutnya disterilkan dalam autoclave pada suhu $121^{\circ} \mathrm{C}$ selama 15 menit. Setelah proses sterilisasi, media diangkat dan dimiringkan dengan posisi $15^{\circ}$ dan dibiarkan mengeras. Media ini berfungsi sebagai tempat untuk peremajaan bakteri.

\section{Pembuatan Media Lapisan Dasar}

Media yang digunakan adalah agar $3,5 \mathrm{~g}$ dilarutkan dalam $250 \mathrm{ml}$ akuades di atas penangas. Selanjutnya disterilkan dalam autoclave pada suhu $121^{\circ} \mathrm{C}$ selama 15 menit. Setelah itu media dituangkan ke dalam cawan petri sebanyak $15 \mathrm{ml}$ dan dibiarkan sampai mengeras.

\section{Pembuatan Suspensi Bakteri}

Bahan pembuatan suspensi bakteri yang digunakan adalah Brainheart Infusion (BHI) sebanyak 6,3 g, dilarutkan dalam 150 $\mathrm{ml}$ akuades di atas penangas. Selanjutnya disterilkan dalam autoclave pada suhu $121^{\circ} \mathrm{C}$ selama 15 menit. Setelah proses sterilisasi, media diangkat dan didinginkan. Media ini digunakan untuk memperoleh konsentrasi bakteri yang sesuai untuk pengujian di laboratorium.

\section{Pembuatan Media Pembenihan}

Pembuatan media pembenihan dengan menggunakan agar mullerhinton (MHA) sebanyak $13 \mathrm{~g}$, agar $3 \mathrm{~g}$, dilarutkan dalam $300 \mathrm{ml}$ akuades di atas penangas. Selanjutnya disterilkan dalam autoclave pada suhu $121^{\circ} \mathrm{C}$ selama 15 menit. Setelah itu diangkat kemudian dituangkan di atas lapisan dasar petridish. 


\section{Pembuatan Standar Kekeruhan (Turbidity Standart/Mac Farland)}

Standar kekeruhan dibuat dengan melarutkan $0,5 \mathrm{ml} \mathrm{BaCl}_{2}, 2 \mathrm{H}_{2} \mathrm{O} 1,175 \%$ dan $99,5 \mathrm{ml}, \mathrm{N}_{2} \mathrm{SO}_{4} 0,36 \mathrm{~N}$ dalam tabung reaksi sebanyak $10 \mathrm{ml}$.

\section{Peremajaan Bakteri dan Penanaman Lapisan Pembenihan}

Bakteri dikultur pada media agar miring dengan cara mengambil koloni dari stok bakteri yang telah tersedia. Koloni bakteri diambil dari stok dengan menggunakan kawat ose steril dan digoreskan pada media agar. Setelah itu, agar miring diinkubasi pada suhu $37^{\circ} \mathrm{C}$ selama 24 jam. Selanjutnya koloni bakteri dari media agar miring diambil dengan menggunakan kawat ose steril dan dimasukkan ke dalam tabung reaksi berisi media $\mathrm{BHI}$.

Pada media pembenihan bakteri (media MHA) ditanami bakteri uji yang berasal dari media $\mathrm{BHI}$ dengan menggunakan lidi kapas steril. Pertama-tama lidi kapas steril dicelupkan ke dalam suspensi bakteri hingga basah. Setelah itu diangkat dari dalam cairan dan diperas dengan cara menekan sambil diputar pada dinding tabung bagian dalam. Selanjutnya lidi kapas digoreskan di atas media lapisan pembenihan sebanyak 3 kali masing-masing dengan posisi yang berbeda. Kemudian pada setiap akhir penggoresan cawan petri diputar $60^{\circ}$ sampai goresan merata seluruh bagian atas media pembenihan.

\section{Pengujian Aktivitas}

Hasil ekstrasi dari alga diteteskan dengan menggunakan mikropipet sebanyak $100 \mu \mathrm{l}$ pada sumur yang telah dibuat pada media pembenihan bakteri. Pada sumur yang berbeda juga dimasukkan larutan antibiotik sebagai pembanding positif yaitu ciprofloxacin. Setelah itu diinkubasi pada suhu $37^{\circ} \mathrm{C}$ selama 24 jam.

Apabila larutan uji menghambat pertumbuhan bakteri maka akan terlihat zona terang di sekitar lubang sumur. Artinya tidak terdapat pertumbuhan bakteri di zona terang tersebut. Selanjutnya dilakukan pembandingan dengan zona terang yang terbentuk oleh antibiotik pembanding. Apabila sampel uji tidak menghambat pertum- buhan bakteri maka tidak akan terlihat zona terang di sekitar lubang sumur.

\section{HASIL DAN PEMBAHASAN}

Hasil penelitian Insan dan Widyartini (2008) Caulerpa racemosa diketahui bersifat racun terhadap beberapa organism laut. Hasil dan ekstrak $C$. racemosa dapat diisolasi senyawa kimia seperti caulerpicin, caulerpin dan sterol. Caulerpicin menimbulkan rasa pedas dan menyebabkan efek anesthesia yang ringan bila ditempelkan pada mulut sehingga aktivitas neurotropik ini mempunyai nilai klinik. Izzati, M (2007) berdasarkan hasil penelitian menunjukkan C. racemosa memiliki aktivitas antibakteri terhadap tiga jenis bakteri pathogen yaitu Pseudomonas pavanaceae, Pseudomonas syntata, dan Pseudomonas tetrolens.

Hasil pengujian aktivitas antibakteri menunjukkan bahwa larutan uji dari alga $C$. racemosa, memiliki aktivitas antibakteri pada 3 bakteri dari 5 bakteri uji yang diujikan. Ukuran zona hambat yang terbentuk relatif lebih kecil, jika dibandingkan dengan ukuran zona hambat yang dibentuk oleh senyawa antibiotika pembanding. Hasil pengukuran diameter zona hambat dapat dilihat padaTabel 1.

Tabel 1. Diameter rata-rata Zona Hambat (satuan $\mathrm{mm}$ )

\begin{tabular}{llccc}
\hline \multirow{2}{*}{ No } & \multirow{2}{*}{$\begin{array}{c}\text { Nama } \\
\text { Bakteri }\end{array}$} & $\begin{array}{c}\text { C. } \\
\text { racemosa }\end{array}$ & \multicolumn{2}{c}{ Senyawa Pembanding } \\
\cline { 3 - 5 } & & Siprofloksasin & Akuades \\
\hline 1 & E. tarda & 1,3 & 2,80 & - \\
2 & S. dysentriae & - & 2,83 & - \\
3 & Y. enterocolitica & 1,4 & 2,45 & - \\
4 & P. stuartii & 1,3 & 2,33 & - \\
5 & S. parathypi & - & 2,71 & - \\
\hline
\end{tabular}

Berdasarkan hasil pengukuran zona hambat, larutan uji ekstrak alga, $C$. racemosa, $B$. dapat menghambat tiga dari lima jenis bakteri uji. Pengukuran zona hambat rata-rata ekstrak alga $C$. racemosa berturut-turut adalah bakteri $E$. tarda dengan diameter zona hambat sebesar 1,3 $\mathrm{mm}$. Bakteri Yersinia enterocolitica dengan diameter zona hambat sebesar 1,4 $\mathrm{mm}$ dan bakteri Proteus stuartii dengan diameter zona hambat sebesar $1,3 \mathrm{~mm}$. Diameter zona hambat dari larutan uji dan senyawa pembanding dapat dilihat pada Gambar 1. 

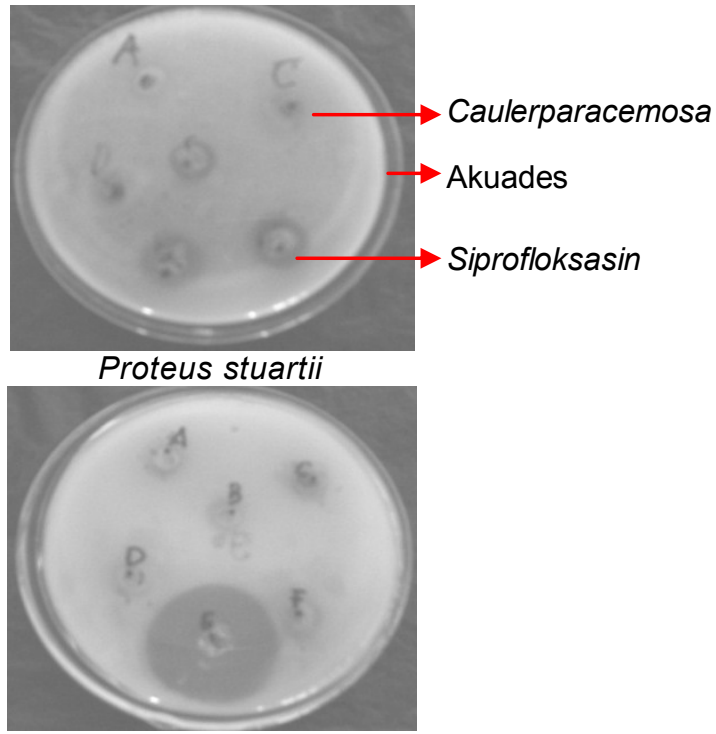

Edwardsielatarda

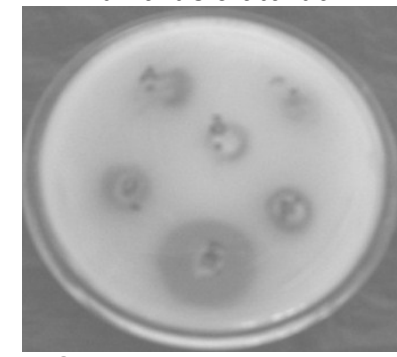

Salmonella paratiphy

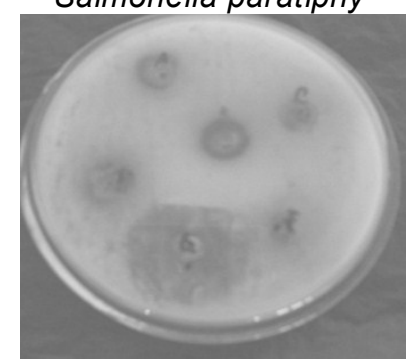

Shigelladysentriae

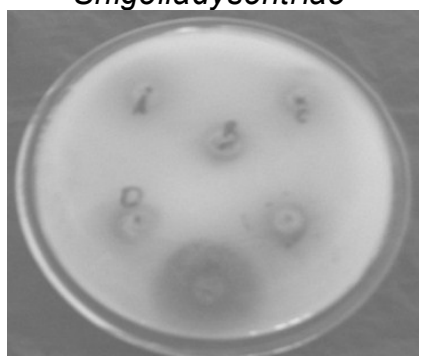

Yersinia enterocolitica

Gambar 1. Zona hambat dari larutan uji dan senyawa pembanding

Dari hasil uji aktivitas antibakteri dapat dilihat ukuran zona hambat yang terbentuk oleh ciprofloksasin lebih besar dan lebih baik dari pada empat larutan uji yang digunakan, sedangkan untuk akuades tidak terbentuk zona hambat. Diperoleh demikian karena ciri-ciri efektifnya suatu zat antibakteri adalah memiliki zona hambat yang luas dan bersih (tidak ditumbuhi bakteri).
Menurut Subari et al. (1994) dalam Banteng (2001) antibiotika ciprofloksasin merupakan antibiotika dengan kegiatan luas, yaitu antibiotika yang aktivter hadap banyak jenis bakteri, virus dan protozoa. Akuades sebagai larutan kontrol dari sampel uji tidak menunjukan adanya aktivitas antibakteri bila dibandingkan dengan ekstrak masingmasing jenis alga. Hal ini dapat dilihat dengan tidak adanya zona hambat yang terbentuk pada media bakteri sehingga akuades sebagai larutan kontrol tidak ada pengaruhnya terhadap larutan uji ekstrak alga dalam pengujian aktivitas antibakteri.

\section{KESIMPULAN}

Berdasarkan hasil penelitian uji aktivitas antibakteri pada alga laut $C$. racemosa, maka dapat disimpulkan bahwa alga laut ini memiliki senyawa yang mengandung aktivitas antibakteri pada Edwardsiela tarda, Yersinia enterocolitica dan Proteus stuartii.

\section{DAFTAR PUSTAKA}

ATCC, 2007. http:// www.atcc.org/ search/ catalogs/ logview.cfm./ 3 Maret 2007.

Atmadja, W. S. 1996. Pengenalan JenisJenis Rumput Laut Di Indonesia. Puslitbang Oseanologi LIPI. Jakarta 191 hal.

Banteng, M. 2001. Uji Aktivitas Antibakteri Pada Kepiting Raja (Carcinus corpiusrotundicauda (Latreille). Skripsi. FPIK. Universitas Sam Ratulangi. Manado. (tidak dipublikasikan)

Beveridge,M. C. M. 1987. Cage Aquaculture .Fishing News Book. Ltd. Farmer. Surey. England.

Bold, H. C. dan M. J. Wynne. 1985. Development In Aquaculture And Fisheries Science. Volume 16. Seaweed Cuktivation For Renewable Resources. Elsevier. Amsterdam. 381 hal.

Dawes C. J. 1998. Marine Botany. Second Edition A Wiley Interscience Publication. The United State America.

Duxbury, A. C. dan A. B. Duxbury. 1989. Oceans: An Introduction to the World. Wm. C. Publisher. USA. 
Mubarak, H., S. Ilyas., W. Ismail., I. S. Wahyuni., S.T. Hartati., Z. Jangkuru dan R. Arifudin. 1990. Petunjuk Teknis Budidaya Rumput Laut. Badan Penelitian dan Pengembangan Pertanian. Pusat Penelitian dan Pengembangan Perikanan. Jakarta. 93 hal.

Nontji, A. 1993. Laut Nusantara. Suatu Pendekatan Ekologis. Penerbit Djambatan. 367hal.

Insan dan Widyartini, 2008. Jenis-jenis Rumput Laut yang Berpotensi Sebagai Obat yang tumbuh pada Berbagai
Subtrat di Pantai Ranababakan Nusa Kambangan, Cilacap.

Izzati, M, 2007. Skreening Potensi Anti Bakteri pada Beberapa Spesies Rumput Laut terhadap Bakteri Patogen pada Udang Windu.Jurnal Bioma. Vol. 9. No. 2.

Trono, G. C. 1997. Field Guide And Atlas Of The Seaweed Resources Of The Philippines. Bookmark, Inc. Makaty City. 306 hal. 